\title{
UPAYA PENYELESAIAN SENGKETA PADA SEKTOR BISNIS PARIWISATA DI TENGAH PANDEMI COVID 19
}

\author{
Nasrudin \\ Fakultas Syari'ah dan Hukum UIN Sunan Gunung Djati Bandung \\ E-mail: anazhaitami@uinsgd.ac.id
}

\begin{abstract}
Tourism is one of the new style industries, which is able to provide rapid economic growth in terms of employment opportunities, income, standard of living and in activating other production sectors in tourist-receiving countries. While business is an activity to make a profit. In running a business, sometimes there are disputes between business actors and other business actors. Sometimes disputes that occur are due to a party defaulting and the other party feels disadvantaged. Broadly speaking, in Indonesia there are two pathways to resolve disputes namely litigation and nonlitigation. The Litigation Path is a settlement effort made in the Court, while the non-litigation path is the settlement effort that is carried out outside the court. This study uses a type of library research, then this study uses a normative qualitative approach. The results of this study conclude that business disputes can occur at any time without exception when the outbreak of Covid 19. For example, the tourism business sector whose turnover has now declined dramatically because there are government regulations that require at home and not traveling. The decline in the turnover of the tourism business sector has made companies negligent, such as not paying full salaries to employees and being late in paying taxes. Such events can lead to disputes between companies and individuals. One of the efforts taken in resolving this dispute was mediation, while the mediation used was electronic mediation considering that the Covid 19 pandemic is not yet over.
\end{abstract}

Keywords:

business law, dispute resolution efforts;,Covid 19

DOI: 10.15575/adliya.v14i1.8564 


\begin{abstract}
Abstrak
Pariwisata merupakan salah satu dari industri gaya baru, yang mampu menyediakan pertumbuhan ekonomi yang cepat dalam hal kesempatan kerja, pendapatan, taraf hidup dan dalam mengaktifkan sektor produksi lain di dalam negara penerima wisatawan. Sedangkan Bisnis merupakan suatu kegiatan untuk memperoleh keuntungan. Di dalam menjalankan bisnis, adakalanya ditemui perselisihan antara pelaku usaha dengan pelaku usaha lainnya. Terkadang sengketa yang terjadi adalah karena adanya salah satu pihak yang melakukan wanprestasi dan pihak lain merasa dirugikan. Secara garis besar, di Indonesia ada dua jalur untuk menyelesaikan sengketa yaitu jalur litigasi dan non-litigasi. Jalur Litigasi merupakan upaya penyelesaian yang dilakukan di Pengadilan, sedangkan jalur nonlitigasi yaitu upaya penyelesaian yang dilakukan di luar pengadilan. Penelitian ini menggunakan jenis penelitian kepustakaan, dengan pendekatan kualitatif normatif. Hasil penelitian ini menyimpulkan bahwa sengketa bisnis dapat terjadi kapan saja tidak terkecuali saat mewabahnya Covid 19. Sebagai contoh sektor bisnis pariwisata yang kini omsetnya menurun drastis karena ada peraturan pemerintah yang mengharuskan dirumah saja dan tidak bepergian. Menurunnya omset sektor bisnis pariwisata menjadikan perusahaan lalai, seperti tidak membayar full gaji kepada pegawai dan telat dalam membayar pajak. Peristiwa seperti itu dapat menimbulkan sengketa antara perusahaan dengan individu. Upaya yang dilakukan dalam menyelesaikan sengketa ini salah satunya dilakukan upaya mediasi, adapun mediasi yang digunakan adalah mediasi elektronik mengingat saat ini pandemi Covid 19 belum sepenuhnya berakhir.
\end{abstract}

\title{
Kata-kata kunci:
}

hukum bisnis, upaya penyelesaian sengketa, Covid 19 


\section{Pendahuluan}

Salah satu upaya yang dilakukan oleh manusia untuk memenuhi kebutuhan hidupnya ialah melalui aktivitas bisnis. Mengingat aktivitas bisnis ini terjadi dalam lingkup kehidupan manusia sehari-hari, yaitu masyarakat, maka tidak mengherankan apabila aktivitas tersebut juga membutuhkan lembaga hukum, yang disebut dengan lembaga hukum bisnis, untuk mengatur segala sesuatu yang berkaitan dengannya. Hal ini tentunya sejalan pula dengan adagium Yunani, yaitu ubi societas, ibi ius, yang berarti di mana ada masyarakat, di situ ada hukum ${ }^{1}$.

Ada beberapa istilah yang berbeda-beda, namun jika dilihat dari maknanya akan mengacu kepada makna hukum yang mengatur aktivitas bisnis. Istilah-istilah tersebut, antara lain, ialah hukum dagang, hukum perniagaan, hukum ekonomi, dan hukum bisnis. Istilah hukum bisnis tersebut lebih luas ruang lingkupnya dan tetap cocok dengan keadaan kekinian, baik dalam hal konsep, kenyataan di lapangan ataupun praktik, daripada beberapa istilah lainnya yang cenderung memiliki pengertian yang serupa, yaitu seperti istilah hukum dagang, hukum perniagaan, dan hukum ekonomi².

Menurut Munir Fuady, hukum bisnis merupakan suatu perangkat kaidah hukum (termasuk law enforcement-nya) yang mengatur tentang cara-cara pelaksanaan urusan atau kegiatan dagang, industri atau keuangan yang dihubungkan dengan produksi atau pertukaran barang atau jasa dengan menempatkan uang dari para entrepreneur dalam risiko tertentu dengan usaha tertentu dengan motif (dari entrepreneur tersebut) adalah untuk mendapatkan keuntungan tertentu 3 .

Pariwisata merupakan salah satu dari industri gaya baru, yang mampu menyediakan pertumbuhan ekonomi yang cepat dalam hal kesempatan kerja, pendapatan, taraf hidup dan dalam mengaktifkan sektor produksi lain di dalam negara penerima wisatawan4. Sedangkan Bisnis merupakan suatu kegiatan untuk memperoleh keuntungan, semua orang atau individu maupun kelompok melakukan kegiatan bisnis pastinya untuk mencari keuntungan agar kebutuhan hidupnya terpenuhi, tidak ada orang yang

1“Ubi Societas, Ibi Ius,” <http://www.oxfordreference.com/view/ 10.1093/ acref/9780195369380.001.0001/acref-9780195369380-e-2028>, diakses pada tanggal 15 April 2020.

2 Rudyanti Dorotea Tobing, Aspek-Aspek Hukum Bisnis: Pengertian, Asas, Teori dan Praktik, (Surabaya: Laksbang Justitia, 2015), hlm. 57-59.

${ }^{3}$ Ibid., hlm. 60

4 Wahab Salah, Manajemen Kepariwisataan, (Jakarta: Pradnya Paramitha, 2003), hlm. 5 
melakukan bisnis untuk mencari kerugian ${ }^{5}$. Orang-orang tentu sudah sangat akrab dengan kata bisnis. Bisnis menjadi peluang usaha bagi orangorang yang tidak mampu bekerja dibawah tangan orang lain. Menjadi pelaku usaha harus cakap dalam berbagai hal, termasuk harus mengetahui hukum yang mengatur di dalamnya. Di dalam menjalankan bisnis, adakalanya ditemui perselisihan antara pelaku usaha dengan pelaku usaha lainnya. Terkadang sengketa yang terjadi adalah karena adanya salah satu pihak yang melakukan wanprestasi dan pihak lain merasa dirugikan. Dalam menyelesaikan permasalahannya para pihak bebas menentukan jalur yang akan diambil.

Jalur penyelesaian sengketa terdapat dua jenis yaitu jalur litigasi dan non-litigasi. Menurut Suyud Margono berpendapat bahwa litigasi adalah gugatan atas suatu konflik yang diritualisasikan untuk menggantikan konflik sesungguhnya, dimana para pihak memberikan kepada seorang pengambilan keputusan dua pilihan yang bertentangan ${ }^{6}$. Litigasi merupakan proses penyelesaian sengketa di pengadilan, di mana semua pihak yang bersengketa saling berhadapan satu sama lain untuk mempertahankan hak-haknya di muka pengadilan. Hasil akhir dari suatu penyelesaian sengketa melalui litigasi adalah putusan yang menyatakan win-lose solution $^{7}$. Prosedur dalam jalur litigasi ini sifatnya lebih formal (very formalistic) dan sangat teknis (very technical). Seperti yang dikatakan J. David Reitzel "there is a long wait for litigants to get trial", jangankan untuk mendapat putusan yang berkekuatan hukum tetap, untuk menyelesaikan pada satu instansi peradilan saja, harus antri menunggu ${ }^{8}$.

Sedangkan Penyelesaian sengketa melalui non-litigasi jauh lebih efektif dan efisien sebabnya pada masa belakangan ini, berkembangnya berbagai cara penyelesaian sengketa (settlement method) di luar pengadilan, yang dikenal dengan ADR dalam berbagai bentuk, yaitu: Arbitrase, Negosiasi, Mediasi, Konsiliasi, dan Penilaian Ahli 9 .

5 Sukirno Sadono, Makroekonomi. Teori Pengantar, Edisi Ketiga, (Jakarta: PT. Raja Grasindo Perseda, 2010), hlm. 20

6 Suyud Margono, Penyelesaian Sengketa Bisnis: Alternative Dispute Resolution (ADR) : Teknik \& Strategi Dalam Negosiasi, Mediasi \& Arbitrase, (Bandung: Pustaka Reka Cipta, 2015), hlm. 34

${ }^{7}$ Nurnaningsih Amriani, Mediasi Alternatif Penyelesaian Sengketa di Pengadilan, (Jakarta: Grafindo Persada, 2012), hlm. 16.

8 Yahya Harahap, Hukum Acara Perdata Tentang Gugatan, Persidangan, Penyitaan, Pembuktian, dan Putusan Pengadilan, (Jakarta: Sinar Grafika, 2009), hlm. 233.

${ }^{9}$ Yahya Harahap, hlm. 236. 
Mewabahnya Covid 19 menimbulkan dampak diberbagai bidang, salah satunya adalah banyak menimbulkan sengketa bagi para pelaku usaha. Selama Pandemi Covid 19 yang terjadi, dunia mengalami banyak kerugian. Begitu juga dengan Indonesia yang mengalami kerugian, sehingga muncul sengketa-sengketa yang terjadi pada sektor bisnis. Di Indonesia sudah tercatat beberapa sektor bisnis yang mengalami kesulitan untuk mempertahankan usahanya. Baik dalam tingkat bisnis kecil, menengah atau atas. Sektor bisnis yang sangat terdampak dari adanya pandemi Covid 19 ini adalah sektor pariwisata. Para pelaku usaha di sektor pariwisata tersebut mengalami beberapa sengketa baik dengan pegawai maupun dengan pemerintah.

Dari penjelasan di atas, penulis mengkhususkan sebuah penelitian terhadap kerugian yang dialami para pelaku bisnis pada sektor pariwisata di masa Pandemi Covid 19 dan Cara penyelesaiannya yang paling Efektif. Penelitian ini menggunakan jenis penelitian kepustakaan. Di mana sumber atau referensi yang diperoleh diperoleh melalui sumber-sumber dan referensi yang ada hubungannya dengan pembahasan ${ }^{10}$. Karena itu, penelitian tentang Penyelesaian Sengketa pada Sektor Bisnis Pariwisata di tengah Pandemi Covid-19 menggunakan metode penelaahan data dan analisis yang berkembang. Pendekatan kualitatif normatif merupakan salah satu metode pendekatan yang digunakan dalam penelitian ini, sehingga bahan pustaka yang ada digunakan sebagai referensi penelitian ${ }^{11}$.

\section{Hasil dan Pembahasan}

\section{Tinjauan Umum tentang Sengketa Bisnis}

Hukum Bisnis merupakan sebagian dari aspek yang penting dalam melindungi perilaku dan pelaku usaha yang ada di Indonesia. ${ }^{12}$ Dalam menjalankan bisnis, para pelaku usaha selalu menemukan kendala seperti sengketa ataupun salah satu pihak ada yang melakukan wanprestasi. Dalam menyelesaikan permasalahan sengketa bisnis atau wanprestasi, Indonesia telah menyediakan beberapa lembaga yang dapat ditentukan oleh pelaku usaha untuk menyelesaikan permasalahannya.

Sengketa bisnis terdiri dari dua kata yaitu "sengketa" dan "bisnis". Sengketa diartikan sebagai kejadian yang menyebabkan perselisihan, perbedaan pendapat atau perkara. Perbedaan pendapat terjadi di antara

\footnotetext{
${ }^{10}$ Moh. Nazir, Metode Penelitian (Bandung: Ghalia Indonesia, 2003), hlm. 193.

${ }^{11}$ Suerjono Sukanto dan Sri Mamudji, Penelitian Hukum Normatif Suatu Tinjauan Singkat, Cet. 11 (Jakarta: PT. Raja Grafindo Persada, 2009), hlm. 13-14.

12 Waldi Nopriansyah, Hukum Bisnis di Indonesia (Dilengkapi dengan Hukum Bisnis dalam Perspektif Syariah), (Jakarta: Prenada Media Group, 2019), hlm. 229.
} 
dua orang atau lebih yang memperebutkan sesuatu. Orang-orang di dalamnya memiliki kepentingan dan tujuan yang sama. Pada dasarnya, sengketa adalah bentuk kesenjangan akan hak milik di antara dua orang atau beberapa orang. Sedangkan bisnis dapat diartikan sebagai usaha yang berorientasi pada keuntungan dalam sektor dunia perniagaan, bisnis juga berarti suatu keadaan sekelompok orang atau seseorang yang melakukan usaha untuk mendapatkan atau menghasilkan keuntungan ${ }^{13}$.

Dapat diartikan bahwa sengketa bisnis merupakan bentuk perselisihan dalam kegiatan bisnis atau perniagaan terhadap dua pihak atau lebih yang di dalamnya termasuk pada unsur yang luas, yaitu: penghasilan, profesi, keuntungan, dan pekerjaan. ${ }^{14}$

\section{Macam-macam Penyelesaian Sengketa Bisnis}

Penyelesaian Sengketa Litigasi

Proses penyelesaian sengketa yang dilaksanakan melalui pengadilan atau yang sering disebut dengan istilah "litigasi", yaitu suatu penyelesaian sengketa yang dilaksanakan dengan proses beracara di pengadilan di mana kewenangan untuk mengatur dan memutuskannya dilaksanakan oleh hakim. Proses penyelesaian sengketa ini mengakibatkan semua pihak yang bersengketa saling berhadapan satu sama lain untuk mempertahankan hak-haknya di muka pengadilan. Hasil akhir dari suatu penyelesaian sengketa melalui litigasi adalah putusan yang menyatakan win-lose solution ${ }^{15}$.

Menurut Munir Fuadi, penyelesaian sengketa secara konvensional dilakukan melalui suatu badan pengadilan sudah dilakukan sejak ratusan tahun bahkan ribuan tahun yang lalu16. Di Indonesia penyelesaian sengketa dengan berdasarkan hukum Islam sendiri telah dimulai sejak tahun 1855, seperti yang terdapat pada Regering Reglement yang diperkuat dengan teori Receptio in Complexu yang dikemukakan oleh LWC Van Der Berg. Teori tersebut menyatakan bahwa hukum Islam berlaku untuk keseluruhan umat Islam di Indonesia ${ }^{17}$.

13 Fitrotin Jamilah, Strategi Penyelesaian Sengketa Bisnis, (Yogyakarta: Medpress Digital, 2014), hlm. 12.

${ }^{14}$ Herniati dan Sri Iin Hartini, Sengketa Bisnis dan Proses Penyelesaiannya Melalui Jalur Non Litigasi, (Surabaya: Media Sahabat Cendekia, 2019), hlm. 45.

15 Nurnaningsih Amriani, Mediasi Alternatif Penyelesaian Sengketa Perdata di Pengadilan, (Jakarta: PT. Raja Grafindo Persada, Jakarta, 2012), hlm. 35

16 Munir Fuady, Pengantar Hukum Bisnis, Menata Bisnis Modern di Era Global, (Bandung: Citra Aditya Bakti, 2005), hlm.311

17 Rif'al Ka'bah, Hukum Islam di Indonesia, (Jakarta: Universitas Yarsi, 1999), hlm.73. Lihat juga Muchsin, Kekuasaan Kehakiman yang Merdeka \& Kebijakan Asasi, (Depok: STIH "IBLAM" 2004), hlm.31 
Pada penyelesaian perkara ekonomi syariah di lingkungan peradilan agama akan dilakukan sesuai dengan ketentuan hukum acara perdata sebagaimana berlaku di lingkungan peradilan umum. Artinya, setelah upaya damai ternyata tidak berhasil, maka hakim melanjutkan proses pemeriksaan perkara tersebut di persidangan sesuai ketentuan hukum acara perdata yang dimaksud ${ }^{18}$. Sebagaimana lazimnya dalam menangani setiap perkara yang diajukan kepadanya, hakim selalu dituntut mempelajari terlebih dahulu perkara secara cermat untuk mengetahui substansinya serta ihwal yang senantiasa ada menyertai substansi perkara tersebut.

Jalur litigasi merupakan upaya terakhir dimana para pihak yang bersengketa tidak menemukan titik temu pada saat dilakukan mediasi atau diselesaikan secara kekeluargaan. Pengadilan sebagai lembaga litigasi yang menangani penyelesaian sengketa di antara kedua belah pihak. Dalam prosesnya, pengadilan mengadili sengketa dengan aturan hukum yang berlaku. Untuk kedua belah pihak harus menyiapkan dokumen-dokumen atau berkas dan permasalahan yang akan diajukan ke pengadilan. Setiap pihak yang bersengketa jika sudah masuk ke ranah pengadilan maka hasil akhirnya dapat menghilangkan kepercayaan antara kedua belah pihak, oleh karenanya pengadilan merupakan jalan terakhir untuk menyelesaikan sengketa. ${ }^{19}$

\section{Penyelesaian Sengketa Nonlitigasi}

Penyelesaian sengketa yang tidak melalui pengadilan sering disebut sebagai Alternative Dispute Resolution atau Alternatif Penyelesaian Sengketa. Saat ini, cara penyelesaian sengketa alternatif lebih sering mendapatkan perhatian dan digunakan oleh berbagai kalangan, terutama mereka yang berada dalam dunia bisnis, sebagai cara penyelesaian perselisihan yang perlu dikembangkan untuk mengatasi kemacetan penyelesaian melalui pengadilan ${ }^{20}$

Menurut Takdir Rahmadi, APS merupakan sebuah konsep yang melingkupi berbagai bentuk penyelesaian sengketa selain daripada proses peradilan melalui cara-cara yang sah menurut hukum, baik berdasarkan pendekatan konsesnsus maupun tidak ${ }^{21}$.

${ }^{18}$ Amran Suadi, Penyelesaian Sengketa Ekonomi Syariah: Teori \& Praktik, (Depok: Prenadamedia, 2017), hlm. 18

19 Waldi Nopriansyah, Op. Cit hlm. 232.

20 Djafar Al Bram, Penyelesaian Sengketa Bisnis Melalui Mediasi, (Jakarta: Pusat Kajian Ilmu Hukum Fakultas Hukum Universitas Pancasila, 2011), hlm. 7.

${ }^{21}$ Hadimulyo, Mempertimbangkan ADR Kajian Alternatif Penyelesaian Sengketa di Luar Pengadilan, (Jakarta: ELSAM, 2017), hlm. 24 
Stanford M. Altschul mendefinisikan APS sebagai "a trial of a case before a private tribunal agreed to by the parties so as to save legal costs, avoid publicity, and avoid lengthy trial delays" (suatu pemeriksaan sengketa oleh majelis swasta yang disepakati oleh para pihak dengan tujuan menghemat biaya perkara, meniadakan publisitas dan meniadakan pemeriksaan yang bertele-tele) ${ }^{22}$.

Philip D. Bostwick mengartikan APS sebagai sebuah perangkat pengalaman dan teknik hukum yang bertujuan: (a) menyelesaikan sengketa hukum di luar pengadilan demi keuntungan para pihak; (b) Mengurangi biaya litigasi konvensional dan pengunduran waktu yang biasa terjadi; dan (c) Mencegah terjadinya sengketa hukumm yang biasanya diajukan ke pengadilan ${ }^{23}$.

Frans Winarta dalam bukunya menguraikan pengertian masingmasing lembaga penyelesaian sengketa sebagai berikut ${ }^{24}$ :

Pertama. Konsultasi adalah suatu tindakan yang bersifat "personal" antara suatu pihak tertentu (klien) dengan pihak lain yang merupakan pihak konsultan, dimana pihak konsultan memberikan pendapatnya kepada klien sesuai dengan keperluan dan kebutuhan kliennya.

Kedua, Negosiasi adalah sutau upaya penyelesaian sengketa para pihak tanpa melalui proses pengadilan dengan tujuan mencapai kesepakatan bersama atas dasar kerja sama yang lebih harmonis dan kreatif.

Ketiga, Mediasi adalah cara penyelesaian sengketa melalui proses perundingan untuk memperoleh kesepakatan para pihak dengan dibantu oleh mediator.

Keempat, Konsiliasi merupakan penengah yang bertindak menjadi konsiliator dengan kesepakatan para pihak dengan mengusahakan solusi yang dapat diterima. Konsiliator berfungsi sebagai pihak ketiga yang memberikan usulan jalan keluar bagi para pihak yang bersengketa apabila para pihak tidak dapat menemukan suatu kesepakatan. Namun bukan berarti konsoliator berwenang dalam membuat putusan, semua pelaksanaan penyelesaian sengketa tergantung kepada para pihak yang bersengketa ${ }^{25}$

22 Priyatna Abdurrasyid, Arbitrase \& Alternatif Penyelesaian Sengketa, (Jakarta: PT Fikahati Aneska bekerjasama dengan Badan Arbitrase Nasional Indonesia (BANI), 2002), hlm.10

${ }^{23}$ Ibid.

${ }^{24}$ Frans Hendra Winata, Hukum Penyelesaian Sengketa, (Jakarta: Sinar Grafika, 2012), hlm. 7-8

${ }^{25}$ Herniati dan Sri Iin Hartini, Op. Cit hlm. 47. 
Kelima,Penilaian ahli yaitu merupakan pendapat para ahli untuk suatu hal yang bersifat teknis dan sesuai dengan bidang keahliannya.

Keenam, Arbitrase yaitu suatu kesepakatan berupa klausula arbitrase yang tercantum dalam suatu perjanjian tertulis yang dibuat para pihak sebelum timbul sengketa, atau suatu perjanjian arbitrase tersendiri yang dibuat para pihak setelah timbul sengketa (Pasal 1 angka 3 UndangUndang Nomor 30 Tahun 1999)26. Pada pasal 1 Undang-Undang No.30 Tahun 1990 tentang Arbitrase dan Alternatif Penyelesaian Sengketa dikatakan bahwa Arbitrase adalah cara penyelesaian suatu sengketa perdata di luar peradilan umum yang didasarkan pada perjanjian arbitrase yang dibuat secara tertulis oleh para pihak yang bersengketa. Dengan demikian arbitrase merupakan cara penyelesaian sengketa oleh seorang atau beberapa orang hakim (wasit/arbiter) yang didasarkan pada perjanjian yang dibuat oleh para pihak yang menyatakan bahwa mereka akan tunduk pada danmenaati putusan yang diberikan oleh hakim/para hakim (wasit/arbiter) yang mereka pilih tersebut.

Ketujuh, Ombudsman. Berdasarkan Undang-undang Nomor 37 Tahun 2008 tentang Ombudsman Republik Indonesia merupakan "lembaga Negara yang mempunyai kewenangan mengawasi penyelenggaraan pelayanan publik baik yang diselenggarakan oleh penyelenggara Negara dan pemerintahan termasuk yang diselenggarakan oleh Badan Usaha Milik Daerah (BUMD), Badan Hukum Milik Negara (BHMN), serta badan swasta atau perseorangan yang bertugas menyelenggarakan pelayanan publik tertentu yang sebagian atau seluruh dananya bersumber dari anggaran pendapatan dan belanja Negara dan/atau anggaran pendapatan dan belanja daerah". ${ }^{27}$ Sedangkan Penyelesaian sengketa Ombudsman diatur dalam Peraturan Ombudsman Republik Indonesia Nomor 26 Tahun 2017 tentang Tata Cara Penerimaan, Pemeriksaan, dan Penyelesaian Laporan. ${ }^{28}$

\section{Dampak Virus Corona terhadap Perekonomian di Indonesia}

Tahun 2020 merupakan tahun yang tidak akan pernah dilupakan oleh masyarakat di seluruh dunia, karena ditahun tersebut telah terjadi sebuah pandemi yang menimpa sebagian wilayah dunia dengan menyebarnya Virus Corona atau Covid 19. Virus Corona atau yang biasa

${ }^{26}$ I Made Widnyana, Alternatif Penyelesaian Sengketa dan Arbitrase, Cetakan Ketiga, (Jakarta: PT. Fikahati Aneska bekerjasama dengan Badan Arbitrase Nasional Indonesia (BANI), 2014), hlm. 116

27 Toman Sony Tambunan dan Wilson R.G. Tambunan, Hukum Bisnis, (Jakarta: Prenadamedia Group, 2019), hlm. 356.

28 Ibid, hlm.357. 
disebut dengan Covid 19 adalah virus berbahaya yang menyerang pada sistem pernafasan, virus tersebut berasal dari Kota Wuhan di China yang mulai terdeteksi pada akhir tahun 2019. Virus ini sangat berbahaya dan tidak sedikit dapat memakan korban jiwa. ${ }^{29}$

Penyebaran virus tersebut sangatlah cepat, sehingga membuat sebagian negara di dunia menerapkan sistem lockdown dan social distancing. Lockdown adalah penerapan karantina disuatu wilayah tertentu agar tidak ada warga yang masuk ataupun keluar dari wilayah tersebut, dan social distancing adalah pembatasan jarak antara manusia dengan manusia lainnya. Hal itu dilakukan pemerintah untuk mencegah penyebaran virus tersebut.

Virus Corona atau Covid 19 telah menyebar di Indonesia pada bulan Maret 2020, karena hal tersebut pemerintah membuat kebijakan social distancing seperti di negara lain yang telah terlebih dahulu terdampak oleh virus tersebut. Namun kebijakan pemerintah tidak selalu memberikan dampak positif bagi masyarakat di Indonesia. Adanya pandemi ini membuat perkembangan ekonomi di Indonesia menjadi lambat, sebagian masyarakat Indonesia merasakan sulitnya bertahan hidup ditengah pandemi ini karena kehilangan pekerjaannya terutama bagi masyarakat yang bekerja di dunia bisnis, dengan adanya pandemic tersebut mereka mengakui bahwa penghasilannya berkurang karena masyarakat takut untuk melakukan aktivitas di luar rumah.

Sebagaimana yang kita ketahui, perekonomian merupakan faktor yang sangat penting bagi negara. Karena sebuah negara dapat dikatakan maju dengan melihat dari faktor ekonominya. Jika ekonomi di sebuah negara sudah maju, maka hal itu berdampak pula pada kesejahteraan masyarakatnya. Seperti berkurangnya tingkat kemiskinan. Faktor yang membuat sebuah negara maju dalam bidang ekonominya yang dilakukan oleh negara lain adalah dengan cara masyarakatnya melakukan kegiatan berusaha atau berbisnis.

Dalam dunia bisnis, adanya konsumen merupakan hal yang paling dicari oleh para produsen. Dengan adanya kebijakan pemerintah yang menerapkan sistem lockdown, membuat bisnis tersebut tidak berjalan seperti biasanya.

\section{Sengketa Bisnis yang terjadi di Tengah Pandemi Covid 19}

Salah satu permasalahan bisnis yang hadir di tengah-tengah Pandemi Covid 19 adalah agent travel pariwisata. Maritim Travel yang

${ }^{29}$ https://duta.co/dampak-virus-corona-terhadap-perekonomian-globalkhususnya-di-indonesia, diakses 1 Mei 2020. 
berkantor pusat di Tangerang Selatan merupakan salah satu travel yang melayani perjalanan lokal seperti perjalanan ke Yogyakarta, Bali, Lombok, dan destinasi lainnya yang ada di Indonesia. Selain itu juga perjalanan Internasional khususnya Asia Tenggara dapat dilakoni oleh Maritim Travel. Dijelaskan oleh pemilik Travel tersebut bahwa operasional perusahaannya sudah 3 pekan lebih mengalami pemberhentian total. Dimana Travel tersebut terakhir melayani wisata adalah pada Bulan Maret.

Sejak pemerintah mengumumkan pasien positif Covid 19 di Indonesia, Maritim Travel pun mengalami penurunan dalam pemesanan Ticket. Pemilik bisnis tersebut menuturkan bahwa pembatalan ini banyak dilakukan oleh konsumen karena khawatir tertular Covid 19, selain itu juga belum adanya kepastian dari pemangku kebijakan atau pemerintah kapan pandemi ini akan berakhir. Banyak upaya telah dilakukan oleh perusahaan ini, salah satunya memberikan opsi pilihan dengan cara penundaan perjalanan bukan dengan pembatalan dan memberikan diskon yang menarik kepada konsumen, tetapi usaha ini tetap kurang berhasil. Alasan tersebut akhirnya Maritim Travel membuat kebijakan untuk menutup sementara usaha bisnisnya, dengan harapan dapat memutus mata rantai penyebaran Covid 19 agar mempercepat penanganan oleh Pemerintah.

\section{Jumlah Wisatawan Asing ke Bali}

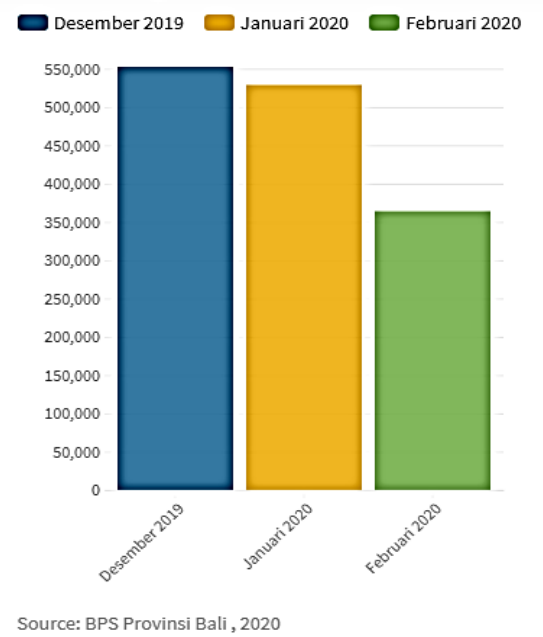

Pihaknya menuturkan, bahwa sebelum Pandemi Covid 19, perusahaan kami rata-rata dapat melayani 10 perjalanan wisata setiap harinya. Sehingga kami mengalami penurunan hingga 300 perjalanan dengan total 
kerugian 200.000.000,-/bulan. Selain itu juga perusahaan kami merumahkan sementara seluruh karyawan sampai ada kepastian dari pemerintah. ${ }^{30}$

Berdasarkan kejadian tersebut tidak menutup kemungkinan akan terjadi persengketaan. Mengapa tidak, menurunnya jumlah konsumen yang menikmati jasa pariwisata karena kebijakan pemerintah yang membatasi wisata karena Covid 19 membuat sektor bisnis pariwisata mengalami penurunan omset yang sangat besar. Menurunnya angka konsumen yang memakai jasa pariwisata membuat perusahaan tidak sanggup untuk membayar pegawai. Pegawai yang bekerja di perusahaan tersebut terpaksa untuk dirumahkan sementara bahkan terkena PHK. Dengan adanya pengurangan pegawai sektor bisnis pariwisata setidaknya tidak membayar gaji lebih banyak dengan omset yang tidak sebanding. Namun pegawai yang terpaksa dirumahkan bahkan yang terkena PHK terkadang tidak diberi pesangon untuk pemberhentiannya dan tidak diberikan gaji full selama ia bekerja pada saat pemerintah menutup sebagian wisata, karena perusahaan merasa tidak sanggup untuk membayar full pegawai. Akhirnya para pegawai yang dirumahkan atau yang terkena PHK merasa dirugikan karena tidak mendapatkan uang yang sebanding dengan pekerjaannya. Disitulah akan timbul sengketa antara perusahaan dan pegawai.

Selain bersengketa dengan pegawai, besar kemungkinan juga perusahaan bersengketa dengan perpajakan. Sebagai sektor bisnis pariwisata yang memiliki transportasi seperti bus tour atau bus travel akan dikenakan pajak, sedangkan melihat keadaan yang sedang terjadi yaitu banyaknya konsumen yang membatalkan perjalanan wisatanya karena peraturan pemerintah agar mengurangi kemungkinan terkena Covid 19 membuat sektor bisnis pariwisata mengalami penurunan omset yang sangat besar. Menurunnya omset karena kurangnya konsumen yang memakai jasa pariwisata mengharuskan perusahaan memenuhi kewajibannya yaitu membayar pegawai dan membayar pajak, namun karena keadaan yang sedang terjadi membuat omset perusahaan kurang untuk dapat memenuhi semua kewajibannya menjadikan perusahaai lalai dan lupa akan membayar pajak. Karena kelalaiannya, sektor bisnis pariwisata akan menimbulkan sengketa dengan pajak pemerintah.

Selain itu juga sebagaimana yang dipaparkan oleh Wakil Ketua Asosiasi Perusahaan Perjalanan Wisata (Asita) Budijanto Ardiansjah mengatakan saat ini 98 persen perusahaan anggota asosiasinya sudah tutup sementara menyusul mewabahnya Virus Corona alias COVID 19. Ia

30https://katadata.co.id/telaah/2020/04/08/tumbangnya-bisnis-perjalanandan-wisata-bali-terpapar-Covid 19, diakses pada 9 mei 2020 20:21 
menyebut setidaknya tiga alasan bagi perusahaan biro perjalanan untuk tak beroperasi dalam kondisi ini. Pertama, kami mematuhi anjuran pemerintah terkait bekerja dari rumah. Kedua, kondisi saat ini pun sudah zero transaction, dan Ketiga adalah untuk efisiensi ${ }^{31}$.

Saat ini jumlah anggota Asita adalah sekitar 7.000 perusahaan dengan total jumlah karyawan berkisar 60 ribu orang di seluruh Indonesia. Adapun dua persen perusahaan yang masih beroperasi, kata Budijanto, menerapkan sistem piket. Namun, apabila hingga akhir bulan ini situasi tidak banyak berubah, diperkirakan mereka juga akan menutup sementara usahanya.

Menurut Budijanto, saat ini status para karyawan di setiap perusahaan berbeda-beda tergantung kebijakan masing-masing perseroan. Ada perusahaan yang merumahkan pegawainya tanpa digaji alias unpaid leave, ada pula perusahaan yang masih memberi gaji pokok dengan potongan.

Kondisi terpuruknya sektor pariwisata akibat pagebluk ini memang membuat beban keuangan perusahaan biro perjalanan menjadi sangat berat. Pasalnya, hingga kini pun para pengusaha perjalanan wisata itu merasa belum ada stimulus yang direalisasikan dan hingga kini masih pada tahap pengajuan. "Pajak kami tetap bayar, BPJS tetap bayar, cicilan kendaraan tetap bayar, belum ada relaksasi perbankan," ujar Budijanto. Belum lagi, mendekati Idul Fitri nanti mereka juga akan dihadapkan dengan kewajiban membayar tunjangan hari raya. "Ini berat karena rata-rata kemampuan pengusaha hanya sampai Juni, tapi peraturan Kementerian Ketenagakerjaan tetap harus membayar THR."

Untuk mengatasi persoalan THR, Budijanto mengatakan setiap perusahaan akan memiliki pendekatan berbeda-beda kepada karyawannya. Beberapa usulan yang sempat mengemuka adalah skema cicilan maupun menunda pembayaran. "Kemungkinannya begitu karena pemerintah menyerahkan mekanisme negosiasinya kepada masing-masing perusahaan," tutur dia. Untuk itu, ia meminta pemerintah segera memberi stimulus tambahan kepada pengusaha pariwisata.

Senada dengan Sekretaris Jenderal (Sekjen) Asosiasi Travel Agent Indonesia (Astindo), Pauline Suharno membenarkan kondisi yang terjadi pada perusahaan agen perjalanan. Ia mengatakan adanya pemberlakuan Pembatasan Sosial Berskala Besar membuat mereka harus menutup sementara operasinya.

${ }^{31}$ https://bisnis.tempo.co/read/1331082/pandemi-corona-98-persen-birotravel-wisata-tutup-sementara, diakses pada 13 April 2020. 
Dengan kondisi tersebut, sejak maret karyawan sudah mulai dirumahkan tanpa menerima gaji. Para pegawai kontrak pun sudah diputus tanpa perpanjangan. "Karyawan ditawari unpaid leave full tanpa tahu sampai kapan atau PHK dengan pesangon yang ditunda bayar karena sekarang ini tidak ada yang sanggup bayar PHK juga," tuturnya. Pasalnya, saat ini penjualan pun turun 95 persen daripada situasi normal dan stimulus pemerintah sampai saat ini masih belum membantu kondisi tersebut.

\section{Cara Penyelesaian yang Efektif Terhadap Sengketa Bisnis yang terjadi di Tengah Pandemi Covid 19}

Sebagaimana yang telah dijelaskan di atas terhadap sengketa bisnis yang dialami oleh Agent Travel Perjalanan Pariwisata baik Maritim Travel, Asosiasi Perusahaan Perjalanan Wisata (Asita), maupun Asosiasi Travel Agent Indonesia (Astindo), penyelesaian yang efektif digunakan adalah dengan cara non-litigasi. Di mana non-litigasi ini menitikberatkan pada mediasi.

Adapun Mediasi yang efektif digunakan pada saat ini adalah dengan Mediasi secara elektronik. Mediasi secara elektonik di era new normal dapat dilaksanakan berdasarkan Perma No. 1 Tahun 2016 Tentang Prosedur Mediasi di Pengadilan. Namun, ada beberapa tantangan yang harus dipersiapkan oleh mediator dan regulator dalam proses pelaksanaan mediasi secara elektronik, diantaranya diperlukan pengaturan lebih teknis soal mediasi elektronik dan membuat sistem yang mumpuni untuk menjaga kerahasiaan informasi.

Selanjutnya, di era pandemi Covid 19 atau new normal ini perlu dicermati terkait bagaimana peran seorang mediator dalam melakukan proses mediasi terhadap para pihak yang bersengketa. Adapun peran tersebut sebagai berikut: Pertama, memberikan motivasi kepada pihak yang bermasalah atau bersengketa bahwa meskipun tengah dilanda wabah tetap bisa menyelesaikan masalah. Kedua, mampu menciptakan kreasi, bahwa mediator harus menggunakan berbagai pendekatan disiplin ilmu yang tepat guna untuk mendukung proses dan mencapai tujuan, yaitu kesepakatan perdamaian. Ketiga, memberikan inovasi, dengan meyakinkan bahwa niat baik yang dilakukan dengan cara baik, serta melalui media yang tepat akan mendapatkan hasil yang baik. Keempat, memberikan inspirasi bahwa mediasi tidak harus dilakukan secara manual, tetapi dapat dilakukan secara elektronik atau daring, dengan menggunakan fasilitas teleconference dan mampu mengambil hikmah dari adanya Covid 19. Salah satu hikmah dari pandemi Covid 19 
ini telah menciptakan budaya baru yang ditandai dengan adanya kebijakan semua negara untuk meningkatkan kesadaran terhadap pentingnya kesehatan, keamanan dan kebersihan untuk memutus mata rantai penyebaran dan penularan Covid 19.

Selain itu juga, dampak dengan adanya pandemi Covid 19 semua kegiatan baik pemerintahan maupun ekonomi dan industri menjadi berkurang atau bahkan terhenti sementara. Sehingga teknologi informatika menjadi salah satu solusi dan menjadi sarana utama dalam menjalankan aktivitas atau bekerja. Perubahan konsep tersebut mengakibatkan semua kegiatan yang sifatnya pertemuan, baik rapat, diskusi, seminar, konferensi baik nasional, regional maupun internasional menggunakan sarana elektronik atau virtual", termasuk dalam pelaksanaan mediasi secara elektronik. Mediasi secara elektronik dapat dilaksanakan dengan dasar hukum yang diatur dalam Perma No. 1 Tahun 2016 pada ketentuan Pasal 5 ayat (3) dan Pasal 6 ayat (2) yang berbunyi: "Pertemuan Mediasi dapat dilakukan melalui media komunikasi audio visual jarak jauh yang memungkinkan semua pihak saling melihat dan mendengar secara langsung serta berpartisipasi dalam pertemuan". (Pasal 5 ayat (3)). "Kehadiran Para Pihak melalui komunikasi audio visual jarak jauh sebagaimana dimaksud dalam Pasal 5 ayat (3) dianggap sebagai kehadiran langsung". (Pasal 6 ayat(2)). Dengan demikian melaksanakan mediasi secara virtual, tidak mengubah norma, bahkan Perma No. 1 Tahun 2016 Pasal 5 ayat (3) dan Pasal 6 ayat (2) sudah mengatur secara tegas. "Perubahannya hanya pada cara dan media yang digunakan untuk melaksanakan kegiatan melalui media elektronik atau virtual."

Dengan kondisi saat ini mediator harus secepatnya melakukan adaptasi dalam menghadapi perubahan yang sangat cepat, baik penguasaannya kepada teknologi informasi, media mediasi secara elektronik dan bahasa pengantar serta memahami nilai-nilai kearifan lokal. Sehingga mediasi berbasis manual harus diubah menjadi mediasi berbasis aplikasi atau elektronik. Dalam pelaksanaan mediasi daring perlu juga diperhatikan untuk menjaga prinsip kerahasiaan dari mediasi itu sendiri. "Prinsip kerahasiaan merupakan salah satu kelebihan dari penyelesaian sengketa melalui mediasi. Mediator harus menjaga kerahasiaan materi mediasi dan para pihak tidak boleh mempublish segala sesuatu yang terjadi di dalam pertemuan atau proses mediasi. Masing-masing pihak harus saling menghormati kerahasiaan tiap-tiap isu dan kepentingan".

Adapun strategi untuk menjamin kerahasiaan proses mediasi secara elektronik dapat dilakukan dengan empat hal berikut: Pertama, mediator 
atau kantor mediator harus memfasilitasi, menyediakan dan menjamin aplikasi khusus (e-filling, e-payment, dan e-process) mediasi yang mampu menjamin kerahasiaan proses mediasi. Kedua, menghindari penggunaan aplikasi yang umum digunakan oleh masyarakat yang tidak mengandung kerahasiaan. Ketiga, mediator atau kantor mediator harus merancang aplikasi khusus, fasilitas khusus mediasi, sehingga para pihak menjadi yakin bahwa masalahnya tidak terekam dan diketahui oleh pihak lain yang tidak berkepentingan. Keempat, para pihak diberikan akses khusus untuk mengetahui perkembangan dan mengikuti proses mediasi.

Pelaksanaan mediasi secara virtual dapat menjawab keterbatasan lintas jarak atau batas. Selain itu juga dapat menghemat waktu karena kita tidak berpindah tempat, bisa di kantor atau di rumah. Kemudian, hemat biaya. Selanjutnya Pengadilan juga bisa menjawab seringnya alasan ketidakhadiran prinsipal," Dengan adanya Perma No. 1 Tahun 2016 dimungkinkan mediasi secara elektronik. Namun, perlu juga mendorong regulator dan pihak terkait untuk membuat peraturan yang mengatur tentang mediasi virtual ini secara lebih rinci dan lebih kuat, "Apakah melalui SEMA, PERMA lainnya yang mengatur bagaimana teknis mediasi virtual ini. Sehingga ada pedoman bagi para pihak yang melaksanakan mediasi virtual terutama untuk menjawab tantangan dari pelaksanaan mediasi virtual."

Setidaknya ada lima tantangan dalam melaksanakan mediasi secara online di era new normal. Pertama, kerahasiaan. "Kita ketahui memang, menggunakan aplikasi yang ada sekarang memang masih rawan hacking dan penyadapan. Kedua, kualitas sinyal atau internet. Di Indonesia belum sepenuhnya merata soal kualitas sinyal atau internet. Kadangkala kita sedang presentasi kemudian mati listrik sehingga sinyal putus. Ketiga, komunikasi non-verbal kurang terdeteksi. Dalam mediasi sengketa emosi para pihak sangat mempengaruhi keberhasilan sebuah mediasi. Menjadi tantangan dalam mediasi virtual, bagaimana kita bisa berdiri, melihat gestur, aplikasi seperti apa. Keempat, kurangnya empati, dan Kelima, penandatangan kesepakatan. Apakah penandatanganan kesepakatan itu cukup dengan transaksi elektronik atau tidak. Namun, setidaknya kita bisa melihat regulasi terbaru ternyata sudah ada di PP No. 80 Tahun 2019 tentang Perdagangan Melalui Sistem Elektronik. Itu sudah memberlakukan kontrak elektronik yang sudah diakui dan berdasarkan UU No. 11 Tahun 2008 tentang Informasi Transaksi Elektronik, juga sudah memberikan ruang. 


\section{Simpulan}

Bisnis merupakan suatu kegiatan untuk memperoleh keuntungan, semua orang atau individu maupun kelompok melakukan kegiatan bisnis pastinya untuk mencari keuntungan agar kebutuhan hidupnya terpenuhi, tidak ada orang yang melakukan bisnis untuk mencari kerugian. Bisnis menjadi peluang usaha bagi orang-orang yang tidak mampu bekerja di bawah tangan orang lain. Menjadi pelaku usaha harus cakap dalam berbagai hal, termasuk harus mengetahui hukum yang mengatur di dalamnya. Di dalam menjalankan bisnis, adakalanya ditemui perselisihan antara pelaku usaha dengan pelaku usaha lainnya. Terkadang sengketa yang terjadi adalah karena adanya salah satu pihak yang melakukan wanprestasi dan pihak lain merasa dirugikan. Dalam menyelesaikan permasalahannya para pihak bebas menentukan jalur yang akan diambil.

Mewabahnya Covid 19 menimbulkan dampak diberbagai bidang, salah satunya adalah timbulnya sengketa bagi para pelaku usaha. Selama Pandemi Covid 19 yang terjadi, dunia mengalami banyak kerugian. Begitu juga dengan Indonesia yang saat ini mengalami kerugian diberbagai sektor, sehingga muncul sengketa-sengketa yang terjadi pada sektor bisnis. Di Indonesia sudah tercatat beberapa sektor bisnis yang mengalami kesulitan untuk mempertahankan usahanya. Baik dalam tingkat bisnis kecil, mengengah atau atas. Sektor bisnis yang sangat terdampak dari adanya pandemi Covid 19 ini adalah sektor pariwisata. Para pelaku usaha di sektor pariwisata tersebut mengalami beberapa sengketa baik dengan pegawai maupun dengan pemerintah.

Salah satu permasalahan bisnis yang hadir di tengah Pandemi Covid 19 adalah Agent Travel Pariwisata. Maritim Travel yang berkantor pusat di Tangerang Selatan merupakan salah satu travel yang melayani perjalanan lokal seperti perjalanan ke Yogyakarta, Bali, Lombok, dan destinasi lainnya yang ada di Indonesia. Selain itu juga perjalanan Internasional khususnya Asia Tenggara dapat dilakoni oleh Maritim Travel. Dijelaskan oleh pemilik Travel tersebut bahwa operasional perusahaannya sudah 3 pekan lebih mengalami pemberhentian total. Dimana Travel tersebut terakhir melayani wisata adalah pada Bulan Maret. Setidaknya tiga alasan bagi perusahaan biro perjalanan untuk tak beroperasi dalam kondisi ini. Pertama, kami mematuhi anjuran pemerintah terkait bekerja dari rumah. Kedua, kondisi saat ini pun sudah zero transaction, dan Ketiga adalah untuk efisiensi.

Mediasi secara elektonik di era new normal dapat dilaksanakan berdasarkan Perma No. 1 Tahun 2016 Tentang Prosedur Mediasi di Pengadilan. Namun, ada beberapa tantangan yang harus dipersiapkan oleh me- 
diator dan regulator dalam proses pelaksanaan mediasi secara elektronik, diantaranya diperlukan pengaturan lebih teknis soal mediasi elektronik dan membuat sistem yang mumpuni untuk menjaga kerahasiaan informasi.

\section{DAFTAR PUSTAKA}

Abdurrasyid, Priyatna. Arbitrase \& Alternatif Penyelesaian Sengketa, Jakarta: PT Fikahati Aneska bekerjasama dengan Badan Arbitrase Nasional Indonesia (BANI), 2002.

Al Bram, Djafar. Penyelesaian Sengketa Bisnis Melalui Mediasi, Jakarta: Pusat Kajian Ilmu Hukum Fakultas Hukum Universitas Pancasila, 2011.

Amriani, Nurnaningsih. Mediasi Alternatif Penyelesaian Sengketa Perdata di Pengadilan, Jakarta: PT. Raja Grafindo Persada, Jakarta, 2012.

Amriani. Nurnaningsih. Mediasi Alternatif Penyelesaian Sengketa di Pengadilan, Jakarta: Grafindo Persada, 2012.

Dampak Virus Corona Terhadap Perekonomian Global Khususnya di Indonesia, $\quad$ https://duta.co/dampak-virus-corona-terhadapperekonomian-global-khususnya-di-indonesia, diakses 1 Mei 2020.

Fuady, Munir. Pengantar Hukum Bisnis, Menata Bisnis Modern di Era Global, Bandung: Citra Aditya Bakti, 2005.

Hadimulyo, Mempertimbangkan ADR Kajian Alternatif Penyelesaian Sengketa di Luar Pengadilan, Jakarta: ELSAM, 2017.

Harahap, Yahya, Hukum Acara Perdata Tentang Gugatan, Persidangan, Penyitaan, Pembuktian, dan Putusan Pengadilan, Jakarta: Sinar Grafika, 2009

Herniati dan Hartini, Sri Iin. Sengketa Bisnis dan Proses Penyelesaiannya Melalui Jalur Non Litigasi, Surabaya: Media Sahabat Cendekia, 2019.

https://bisnis.tempo.co/read/1331082/pandemi-corona-98-persen-birotravel-wisata-tutup-sementara, diakses pada 13 April 2020.

Jamilah, Fitrotin. Strategi Penyelesaian Sengketa Bisnis, Yogyakarta: Medpress Digital, 2014.

Ka'bah, Rifal. Hukum Islam di Indonesia, Jakarta: Universitas Yarsi, 1999.

Margono, Suyud. Penyelesaian Sengketa Bisnis: Alternative Dispute Resolution (ADR): Teknik \& Strategi Dalam Negosiasi, Mediasi \& Arbitrase, Bandung: Pustaka Reka Cipta, 2015.

Muchsin, Kekuasaan Kehakiman yang Merdeka \& Kebijakan Asasi, Depok: STIH “IBLAM” 2004. 
Nazir, Moh. Metode Penelitian, Bandung: Ghalia Indonesia, 2003.

Nopriansyah, Waldi, Hukum Bisnis di Indonesia (Dilengkapi dengan Hukum Bisnis dalam Perspektif Syariah), Jakarta: Prenada Media Group, 2019.

Sadono, Sukirno, Makroekonomi. Teori Pengantar, Edisi Ketiga, Jakarta: PT. Raja Grasindo Perseda, 2010.

Salah, Wahab, Manajemen Kepariwisataan, Jakarta: Pradnya Paramitha, 2003.

Solusi Hadapi Sengketa Usaha saat Pandemi Covid 19, https://mediaindonesia.com/read/detail/310461-solusi-hadapisengketa-usaha-saat-pandemi-Covid 19, diakses pada 09 Mei 2020.

Suadi, Amran. Penyelesaian Sengketa Ekonomi Syariah : Teori \& Praktik, Depok: Prenadamedia, 2017.

Sukanto, Suerjono dan Mamudji, Sri. Penelitian Hukum Normatif Suatu Tinjauan Singkat, Cet. 11, Jakarta: PT. Raja Grafindo Persada, 2009.

Tambunan, Toman Sony dan Tambunan, Wilson R.G. Hukum Bisnis, Jakarta: Prenadamedia Group, 2019.

Tobing, Rudyanti Dorotea, Aspek-Aspek Hukum Bisnis: Pengertian, Asas, Teori dan Praktik, Surabaya: Laksbang Justitia, 2015.

Tumbangnya Bisnis Perjalanan dan Wisata Bali Terpapar Covid 19, https://katadata.co.id/telaah/2020/04/08/tumbangnya-bisnisperjalanan-dan-wisata-bali-terpapar-Covid 19, diakses pada 9 Mei 2020.

Ubi Societas, Ibi Ius, <http://www.oxfordreference.com/view/ 10.1093 /acref/9780195369380.001.0001/acref-9780195369380-e-2028>, diakses pada tanggal 15 April 2020.

Widnyana, I Made. Alternatif Penyelesaian Sengketa dan Arbitrase, Cetakan Ketiga, Jakarta: PT. Fikahati Aneska bekerjasama dengan Badan Arbitrase Nasional Indonesia (BANI), 2014.

Winata, Frans Hendra. Hukum Penyelesaian Sengketa, Jakarta: Sinar Grafika, 2012. 
100 | Adliya: Jurnal Hukum dan Kemanusiaan, Vol. 14, No. 1, Juni 2020 